\title{
Analysis on the Use of Briquettes as an Alternative to Improve the Generation of Thermal Energy in the Locality of Aripuana-Brazil
}

\author{
Haylemar de Nazaret Cardenas-Rodriguez ${ }^{1}$, Rosa Martins ${ }^{2}$, Levy Ely Lacerda Oliveira ${ }^{1}$, Erik Leandro Bonaldi ${ }^{1}$, \\ Frederico de Oliveira Assuncao ${ }^{1}$, Germano Lambert-Torres ${ }^{1} \mathbb{D}$, Helcio Francisco Villa-Nova ${ }^{3}$, \\ Wilson Cesar Sant'Ana ${ }^{1, * \mathbb{D}}$, Luiz Eduardo Borges-da-Silva ${ }^{3}$, Clodoaldo Barboza Bomfin ${ }^{4}$ and Jamil Haddad ${ }^{1}$
}

1 Gnarus Institute, Itajuba 37500-052, MG, Brazil; haylemar@institutognarus.com.br (H.d.N.C.-R.); levy@institutognarus.com.br (L.E.L.O.); erik@institutognarus.com.br (E.L.B.); fredeoa@gmail.com (F.d.O.A.); germanoltorres@gmail.com (G.L.-T.); jamil@excen.com.br (J.H.)

2 Energética SUAPE II S.A., Cabo de Santo Agostinho 54590-000, PE, Brazil; rosa.martins@suapeenergia.com.br

3 Pro-Reitoria de Pesquisa e Pos-Graduacao (PRPPG), Itajuba Federal University, Itajuba 37500-903, MG, Brazil; helcio.villanova@unifei.edu.br (H.F.V.-N.); leborges@unifei.edu.br (L.E.B.-d.-S.)

4 Guaçu Geração de Energia S.A., Aripuanã 78325-000, MT, Brazil; clodoaldo@guacuenergia.com.br

* Correspondence: wilson_santana@ieee.org

Citation: Cardenas-Rodriguez,

H.d.N.; Martins, R.; Oliveira, L.E.L.; Bonaldi, E.L.; Assuncao, F.d.O.;

Lambert-Torres, G.; Villa-Nova, H.F.; Sant'Ana, W.C.; Borges-da-Silva, L.E.; Bomfin, C.B.; et al. Analysis on the Use of Briquettes as an Alternative to Improve the Generation of Thermal Energy in the Locality of Aripuana-Brazil. Energies 2021, 14, 6355. https://doi.org/ 10.3390/en14196355

Academic Editors: Ahmed Koubaa and Flavia Lega Braghiroli

Received: 24 August 2021

Accepted: 3 October 2021

Published: 5 October 2021

Publisher's Note: MDPI stays neutral with regard to jurisdictional claims in published maps and institutional affiliations.

Copyright: (c) 2021 by the authors. Licensee MDPI, Basel, Switzerland. This article is an open access article distributed under the terms and conditions of the Creative Commons Attribution (CC BY) license (https:/ / creativecommons.org/licenses/by/ $4.0 /)$.
Abstract: The city of Aripuana is one of the largest wood producer in the state of Mato Grosso, Brazil. Wood residues are used in the electricity generation at three thermoelectric plants in this region. However, the plants have high costs in transporting the wood residues (due to poor road conditions). Hence, this paper compares the energy performance of wood residues in natura and compacted as briquettes by calculating the heating value and determining the influence of moisture content on the energy characteristics of wood residues. The goal is to demonstrate the viability of using briquettes in order to improve thermoelectric generation. The wood residues from this region are affected by the high humidity of the biome. An alternative to improve the use of energy contained in the wood residues is to produce briquettes with lower humidity. This allows one to maintain high levels of heat energy in a lower volume, facilitating handling and storage. The results show that the use of briquettes improved the performance of thermoelectric plants, generating $1 \mathrm{MW}$ of electricity power with less than 1 ton of briquettes. This contributes to the preservation of the environment, reducing operating costs, transportation and storage of the raw materials.

Keywords: briquettes; heating value; moisture content; wood residue

\section{Introduction}

Brazil is one of the largest wood producers in the world due to its large territorial extension with forest cover. "It is estimated that the amount of wood waste generated in Brazil is approximately 30 million tons/year, of which the wood industry contributes 91\%" [1,2]. "Biomass, if properly managed, offers many advantages, the most important being a renewable and sustainable energy feedstock. It can significantly reduce net carbon emissions when compared to fossil fuels. For this reason, renewable and sustainable fuel is considered a clean development mechanism (CDM) for reducing greenhouse gas (GHG) emissions" [3] (apud [4]). The use of these residues in energy production is an alternative to add value and reduce the impacts caused, as their use in energy production has great advantages (such as changing the energy mix [5]). According with the work of Rosalino and Dalfovo [6], the State of Mato Grosso is one of the main Brazilian states that produce wood in native logs: with 1684 industries and consume about 3.6 million cubic meters of native logs per year. In this scenario, a large amount of unused waste in the state leads to its open burning, which contributes to negative climatic effects. 
According to their morphological characteristics, the residues from the wood industries are classified as [7]:

- chips: particles with maximum dimensions of $50 \times 20 \mathrm{~mm}$, in general coming from the use of chippers;

- $\quad$ wood shavings: residues of less than $2.5 \mathrm{~mm}$;

- sawdust: wood particles with dimensions between 0.5 and $2.5 \mathrm{~mm}$, resulting from the use of saws;

- dust: residues of less than $0.5 \mathrm{~mm}$;

- firewood: larger residues, composed of shorelines, shavings and top log residues.

However, due to the high production of wood residues, the state of Mato Grosso presents a high potential for renewable energy generation. One of the regions with the greatest relevance in the production of wood in the Mato Grosso state is the Aripuanã region - where three thermoelectric power plants fueled by forest residues were implemented aiming the efficient use of residual biomass to generate electricity [8].

As mentioned earlier, the local thermoelectric plants generate electricity using wood waste as fuel, however over the years many sawmill companies in the region have ceased to function and the waste collected by the thermoelectric plants has decreased, compromising the amount established in electricity generation. In addition to the problems associated with the closure of many logging companies, there are problems related to the transport of the raw material. Due to the environmental conditions in the region, there is a long period of rain that (associated with the lack of maintenance) influences the conditions of the roads in the region. Without a good storage of biomass, rain, in addition to making transport difficult, can also influence the energy properties of biomass.

Hence, given the growing interest in producing larger amounts of energy within thermoelectric plants and the aforementioned problems, the characterization of wood residues has been contemplated as one of the main steps for investigating the energy potential. Obtaining information on physical properties, immediate analysis (in order to determine the moisture content), elemental analysis (in order to determine the chemical composition), and heating value are essential for indicating a material as fuel.

The use of biomass as an energy source can be better utilized with a briquette production process. Brazil has great potential in the production of briquettes, as the country has a large amount of biomass that can be used in the best possible way through different devices of briquetting. However, the fact that this process is little known hinders the implementation of this alternative energy source for large-scale use [9].

Briquetting systems have been explored as a sustainable solution [10,11], as it enhances the heating value of biomass. Several works demonstrate the gain in heating value and initiatives for better use and types of briquettes [12]. In particular to the application with briquettes, the best use of biomass is related to biomass densification with controlled drying processes [13]. Drying should be oriented towards a process that achieves densification performance at temperatures of $40-200{ }^{\circ} \mathrm{C}$ and should consider the type of material involved or their combination to achieve moistures between $12 \%$ and $16 \%$ [14]. The pressing processes are also crucial to the performance gain, in addition to the significant volume loss. Studies point to the relationship of briquetting pressure and its mechanical resistance for storage and transport without loss of energy volume [15], with the objective of maximum efficiency in the energy use of biomass. The work of Zago et al. [16] proposed briquetting in the region of Aripuanã, however his approach was focused on the wood industries and not on energy generation.

In this context, the present work aims to evaluate the energy potential of wood residues used as fuel in thermoelectric plants in the region, through the characterization of the biomass, through the determination of the high, low and useful heating values in order to evaluate the influence of moisture in energy properties, as well as in transport and storage. In addition, it is proposed to evaluate the feasibility of transforming such waste into briquettes as an efficient alternative to generation of thermoelectric energy in the region. 
The rest of the paper is organized as follows: Section 2 presents the research methodology. Section 3 presents the obtained results. Finally, Section 4 presents the main conclusions of the work.

\section{Materials and Methods}

The Aripuanã region, located in the northwest of the Mato Grosso state, is located within the Amazon biome, being considered one of the regions with higher timber potential, which allowed the growth of the timber industry in the region. For many years, the residues were dumped by loggers without any control, causing pollution and the emission of gases that affected and harmed the soil and the environment. Considering that these residues become exposed to open air, this implied the risk of fires [16].

The implementation of three thermoelectric power plants powered by forest residues has allowed the efficient use of residual biomass in the generation of electric energy as an alternative to try to solve the problems related to the non-use of residues. These three plants are [8]:

- $\quad$ Nortão: granted power of $1275 \mathrm{~kW}$;

- Conselvan: granted power of $1500 \mathrm{~kW}$;

- Guaçu: installed capacity of 30,000 kW.

The process of obtaining biomass for the generation of electricity within the different thermoelectric plants located in Aripuanã region is based on the gathering of residues in the different timber companies within a radius of $120 \mathrm{~km}$ (the farthest region) to ensure a supply of fuel that allows reaching the amount of electricity generation.

The gathering of wood waste is done by dump trucks, which must deal with the problems related to the region's poor road infrastructure. The poor road conditions are related to the intense rains and the lack of maintenance on them. Figure 1 presents a photograph of one of these roads, where puddles are common and bridges are lost or flooded.

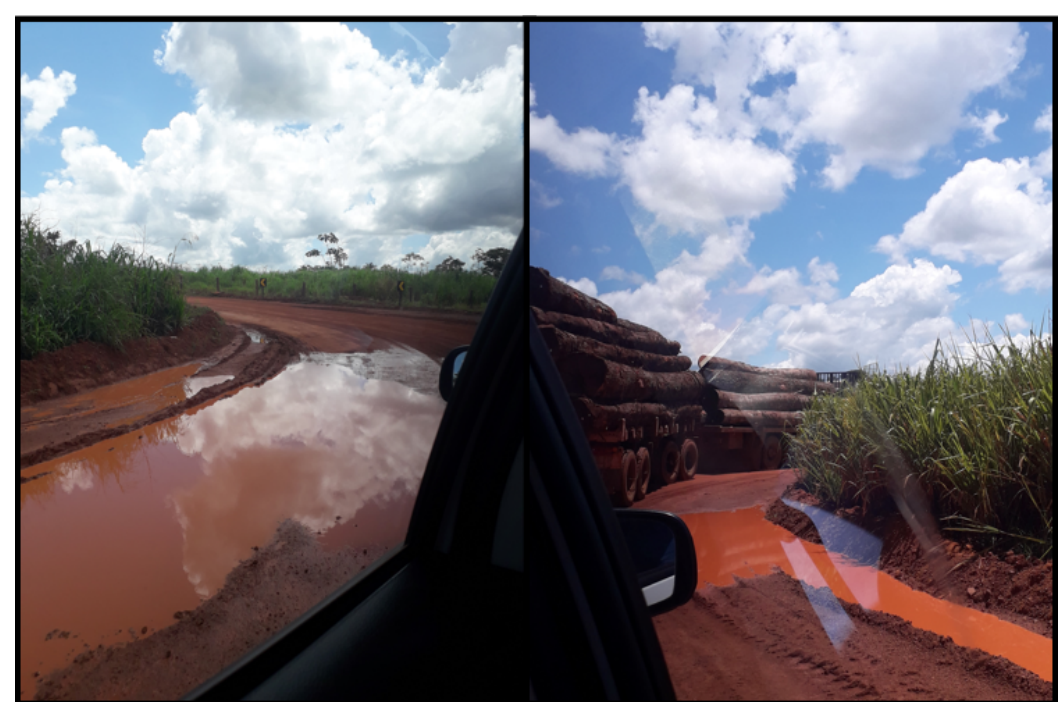

Figure 1. Poor road conditions in the Aripunã region.

\subsection{Gathering and Preparation of the Material}

The characterization of residual biomass is necessary in order to verify the amount of energy stored in it. One important parameter to consider within a thermoelectric plant is the energetic fuel performance-as the generation of electricity in thermoelectric plants is based on the heat produced by the waste combustion in order to produce steam. The most used steam cycle in the processes of converting biomass into thermoelectricity is the Rankine thermodynamic cycle (as it allows the use of different fuel sources, including biomass) [17]. According with the work of Foelkel ([18] pp. 104-105), a characteristic of the Rankine 
cycle is its low efficiency when considering only the generation of electricity (without co-generation). The conversion rate of useful primary energy generated by biomass into electrical energy is typically 15 to $35 \%$. Additionally, small thermoelectric plants, which work with superheated steam under lower pressures, have the lowest efficiencies. The main reason for such low efficiency is the necessity to condensate the steam expelled by the turbine, hence part of the steam energy is lost (whenever co-generation is not used).

The energetic performance of the raw material used in the boilers influences the amount of fuel (waste) needed to generate the amount of energy and, consequently, its transport costs. In order to evaluate the energetic performance of wood waste, it is necessary to determine the heating value and consider other factors that may affect its efficiency.

For the analysis of the energetic performance of the biomass, several samples with different particle sizes were collected from the Aripuanã region. The choice of residues was made randomly, and the wood residues were organized in the form of piles. Table 1 presents the environmental conditions of the locality of Aripuanã on the collection day (15 January 2020).

Table 1. Environmental conditions on the collection day (15 January 2020).

\begin{tabular}{cccc}
\hline Relative Air Humidity & Temperature & Altitude & Location \\
\hline $84 \%$ & $27^{\circ} \mathrm{C}$ & $105 \mathrm{~m}$ & Aripuanã \\
\hline
\end{tabular}

\subsection{Characterization of Biomass Energetic Performance and Procedures}

The particle size classification is an important factor that must be considered in the analysis of energetic performance. The smaller particles create a joining mechanism, which in the case of wood residues facilitates adhesion through the lignin. The samples collected for the study were classified according to particle size as wood shavings, sawdust (light color), sawdust (dark color) and wood chip. Figure 2 presents photographs of each type of sample.

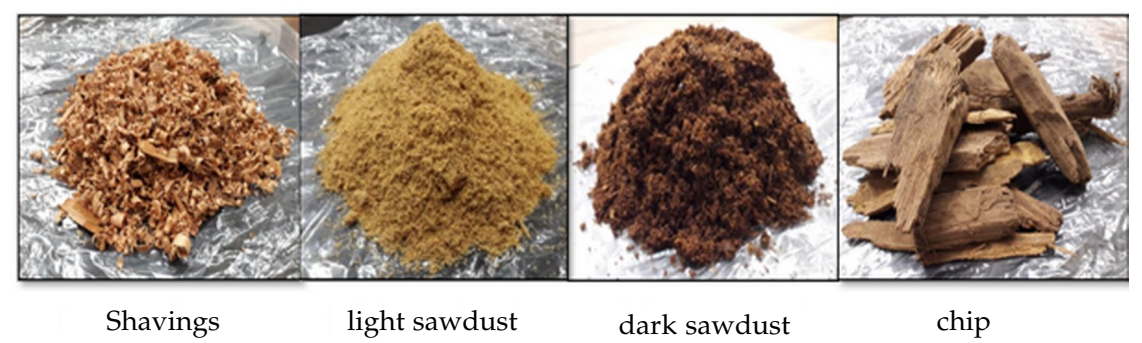

Figure 2. Waste collected.

In order to evaluate the energy performance of a fuel, it is essential to determine its heating value, which according to [19] can be defined as the amount of energy in the form of heat released during the complete combustion of a unit of mass or volume depending on the material fuel, indicating that the greater the heating value, the greater the amount of energy.

Usually, the heating value of every fuel can be characterized by a higher heating value (HHV) and by a lower heating value (LHV), where the difference between them is caused by the heat of evaporation of the water formed from the hydrogen in the material [20]. According with the glossary of the EIA (U.S. Energy Information Administration) [21], the HHV is "a measure of heat content based on the gross energy content of a combustible fuel", while the LHV is "a measure of heat content based on the net energy content of a combustible fuel". Hence, in the HHV, the water vapor formed provides energy to the process [22], while in the LHV, the amount of energy required for condensation of water has to be subtracted [23]. The HHV is determined in a laboratory test. The LHV is calculated using Equation (1) [24] (apud [25]), [26], which takes into consideration the amount of 
hydrogen of the elemental composition of the wood sample. In basis, $6 \%$ of hydrogen content is considered to determine the lower heating value [27].

$$
L H V=H H V-600 \cdot \frac{9 \cdot H}{100},
$$

where $H$ is the hydrogen content (in \%).

In order to know the amount of useful heat released from the fuel, the Useful Heating Value (UHV) must be calculated, which is the amount of heat used to evaporate the formation of water and the fuel moisture [24] (apud [25]), [26]. The UHV is calculated using Equation (2) [24] (apud [25]).

$$
U H V=L H V \cdot(1-M C)-600 \cdot M C ，
$$

where $M C$ is the moisture content.

\subsection{Briquette Production}

According with the work of Quirino and Brito [28], the briquetting process is a very efficient way of concentrating the available biomass energy in a reduced volume. This technique is a mechanical process, where biomass powder or fragments are used to transform it into a solid, dense, low-moisture fuel, with high energy density, having a regular, standardized, and smaller volume. This process is a coherent logistic method, as it allows the transport, storage, and standardization of boiler furnaces for steam generation [29]. Figure 3 presents a visual comparison of a same amount of biomass (184 g) at different processing stages. It can be noted that the briquetting process, in addition to making better use of the energy properties of wood, also manages to reduce the volume of the same weight of material.

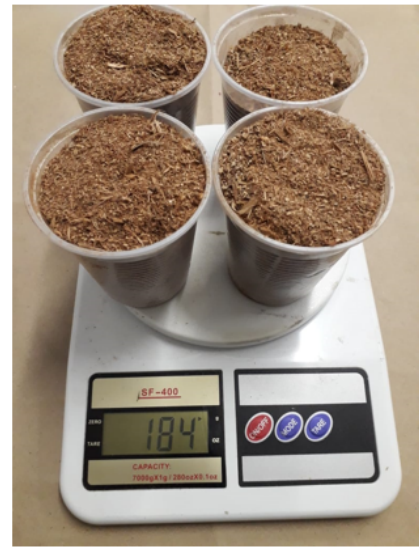

sawdust

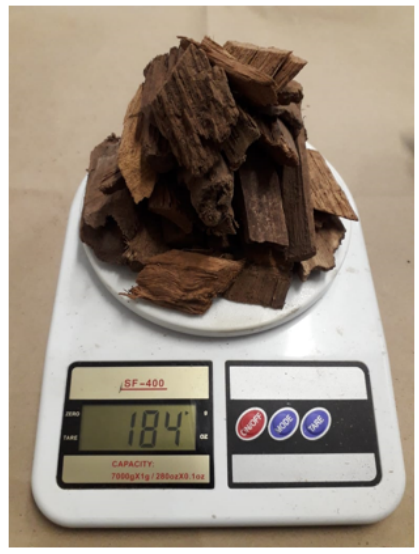

chip

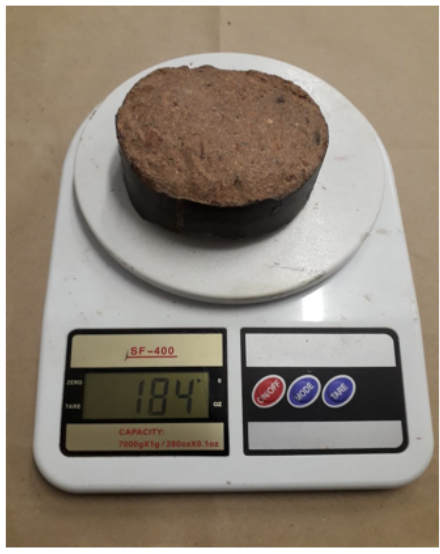

briquette

Figure 3. The same amount of biomass in bulk format and in its compacted form.

The briquetting of wood residues allows the lignin to act as a binder of the biomass particles, as the compaction at high mechanical pressure increases the final briquette temperature level to around $100{ }^{\circ} \mathrm{C}$. The briquetting process must be carried out with particle sizes between 5 and $15 \mathrm{~mm}$ and humidity below $16 \%$.

The briquette production was divided into different stages (screening, drying and briquetting). At the first stage, sawdust and wood shavings particles with size of up to $15 \mathrm{~mm}$ were selected. Then, as a second selection, a rotary sieve was utilized (controlled by an electric motor) with $\varnothing 3 / 4$ inch mesh. Figure 4 presents a photograph of the rotary sieve-where, at the right, can be noted the screening of wood residues using the mesh. 

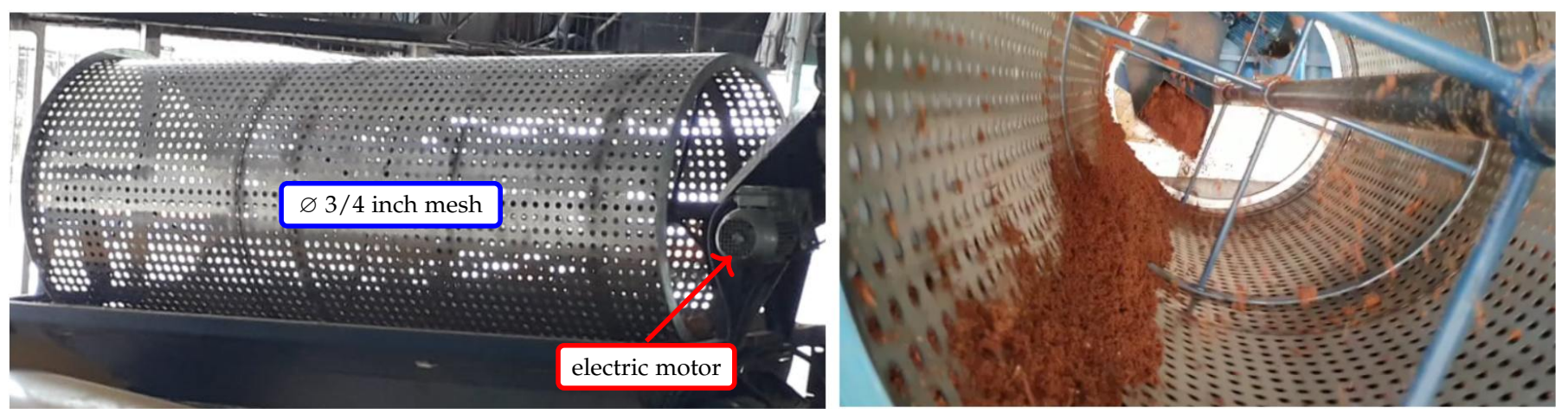

Figure 4. Screening of wood residues.

The briquetting machine of the third stage has a limitation on the maximum moisture content of the raw materials at 16\%. Hence, a second stage (drying) is introduced in the process (in order to adjust the moisture content between $12 \%$ and $10 \%$ ). The $12 \%$ moisture content was chosen because it was within the range considered ideal for the manufacture of briquettes [30]. Figure 5 presents the drying machine. It is based on a rotary drum dryer (with capacity for 2 ton $/ \mathrm{h}$ ) heated in a combustion chamber with internal gas burner with an average drying temperature of $120{ }^{\circ} \mathrm{C}$. The $120^{\circ} \mathrm{C}$ temperature was aimed in order to activate the lignin [31]. The figure also shows a cyclone filter, whose function is to filter the gases produced in the process (in order to reduce the amount of gases thrown into to the atmosphere). Additionally, a conveyor belt is used in order to facilitate the exit of the dry residues, which will be used at the briquetting machine of the third stage of the process.
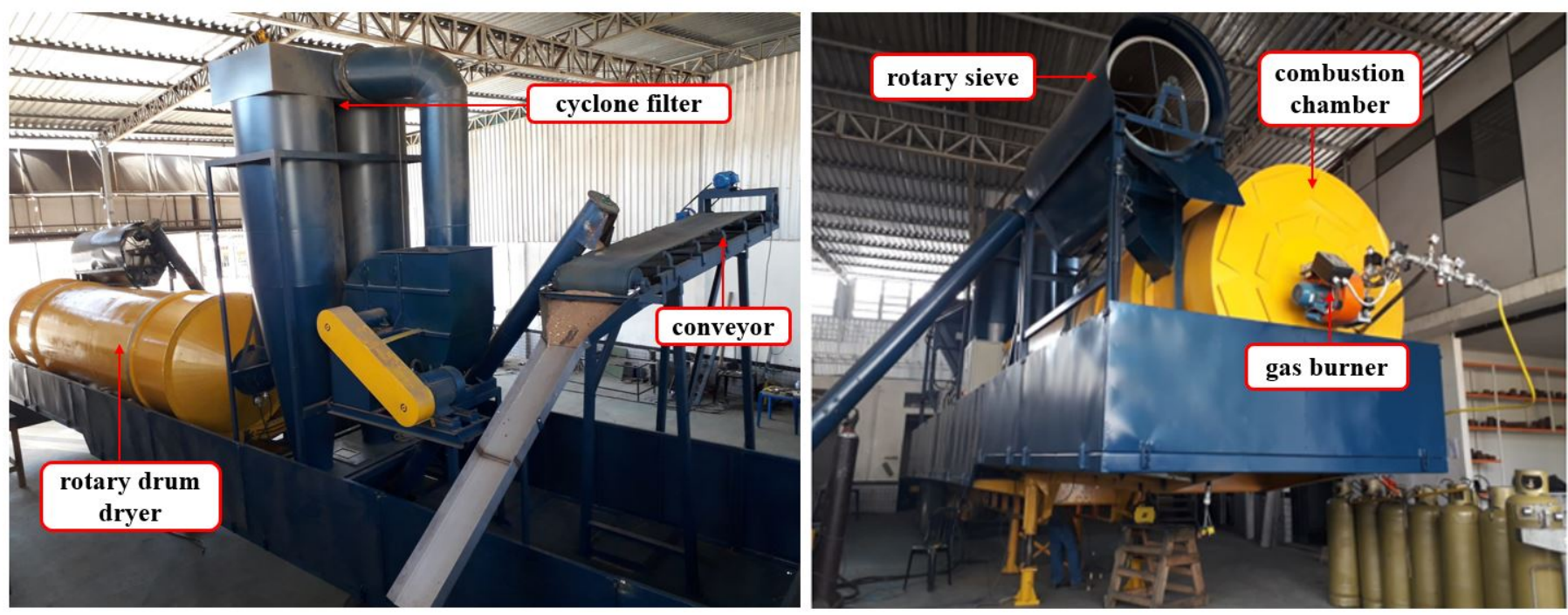

Figure 5. Drying machine.

After drying, the briquetting process is carried out using a mechanical piston briquette machine. The process works with an average mechanical pressure around of $1200 \mathrm{kgf} / \mathrm{cm}^{2}$. Figure 6 presents the briquetting machine-where, at the left, a drawing presents the machine dimensions and its main parts and at the right, a photograph of the actual machine, with a briquette being produced. This machine (model B95/210) has a processing capacity for 1.5 ton/h of wood residues (at a maximum humidity of $16 \%$, which enter the machine at a silo) and is driven by a $75 \mathrm{CV}(\approx 55 \mathrm{~kW})$ electric motor (controlled by frequency inverter). The motor drives a pulley (through a belt), which drives the compression piston. The machine has a height of around $4 \mathrm{~m}$, length of $11 \mathrm{~m}$ and depth of $2 \mathrm{~m}$. 

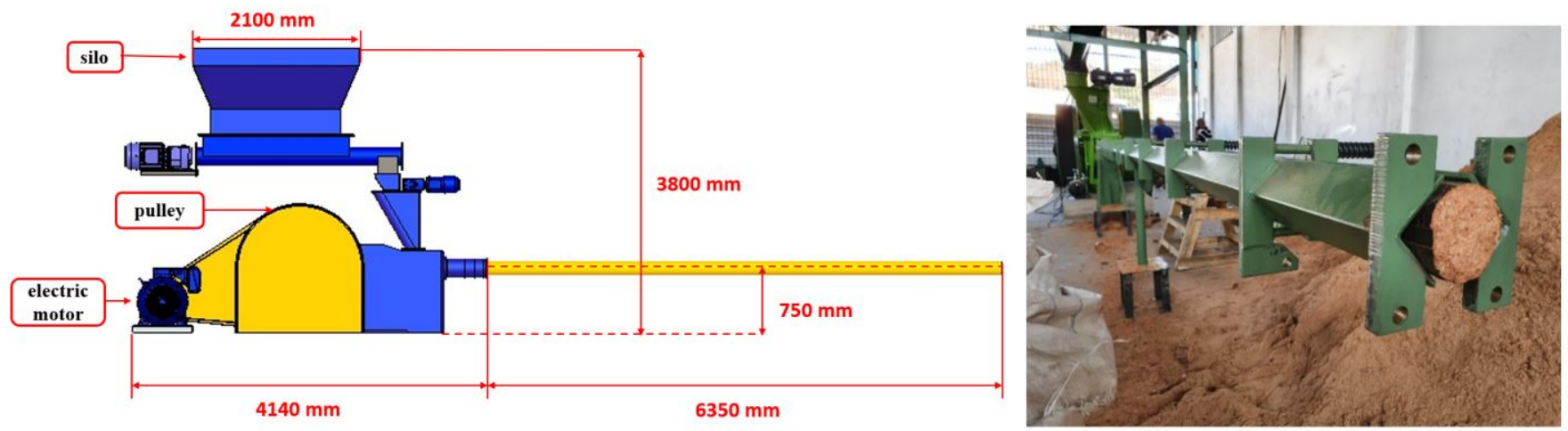

Figure 6. Briquetting machine.

The temperature at compression is around $90{ }^{\circ} \mathrm{C}$. The long tube seeing in Figure 6 has the function to cool down the temperature of the briquettes to around $50{ }^{\circ} \mathrm{C}$ (at the output of the machine). According with the work of Filippetto [32], the cooling is required in order to avoid cracks at the surface of the produced briquettes. From compression to the output, the process takes around $10 \mathrm{~min}$. After its release at around $50{ }^{\circ} \mathrm{C}$ a briquette usually takes $10 \mathrm{~min}$ more to achieve ambient temperature.

According to the manufacturer's specifications, the diameter of the matrix of the briquette machine is $93 \mathrm{~mm}$-however, there is a variation in the diameter of the produced briquettes. This variation is known as the rate of return [28] and is influenced by the moisture content of the material (although it is perfectly normal). Additionally, due to its temperature, the material tends to expand after its release. Figure 7 presents the variation in diameter of the produced briquettes.
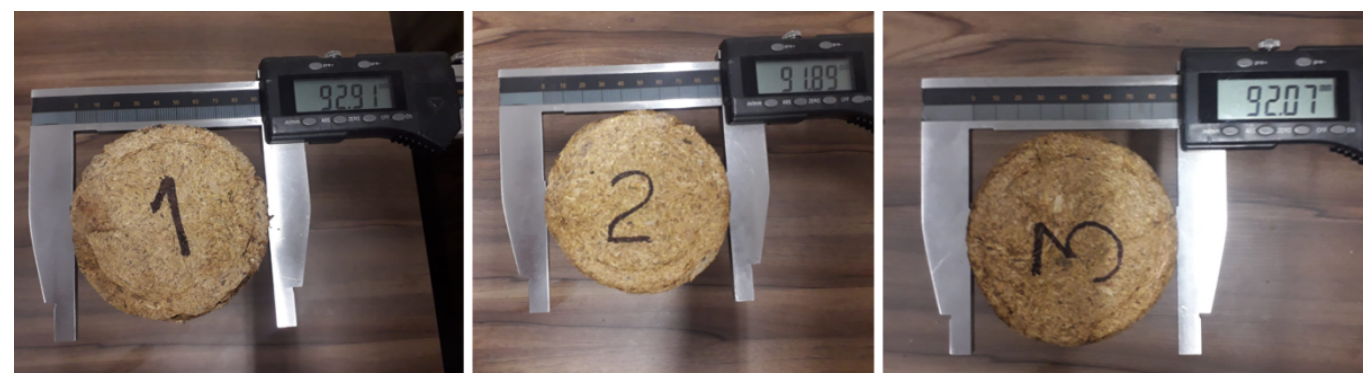

Figure 7. Produced briquettes have a variation in diameter, although perfectly normal.

\section{Results and Discussion}

\subsection{Determination of the Heating Values}

The analysis of the HHV of the materials was carried out in the Wood Panels and Energy Laboratory (LAPEM) of the Forest Engineering Department of the Federal University of Viçosa, located in the municipality of Viçosa, (state of Minas Gerais, Brazil). In this laboratory, a calorimeter (model IKA300) was used to obtain the results presented in Table 2. It is important to note that the certified laboratories in Brazil and their measuring equipment present the measurements of the heating value in $\mathrm{kCal} / \mathrm{kg}$. Hence, another column has been added with these values converted to $\mathrm{MJ} / \mathrm{kg}$.

Table 2. Higher Heating Value (HHV) of different particle sizes (determined in laboratory).

\begin{tabular}{ccc}
\hline Sample Identification & HHV [kcal/kg] & HHV [MJ/kg] \\
\hline wood chips & 4742 & 19.85 \\
wood shavings & 4784 & 20.03 \\
sawdust "light color" & 4802 & 20.11 \\
sawdust "dark color" & 4846 & 20.29 \\
\hline
\end{tabular}


Based on the values of the HHV of Table 2 and considering $6 \%$ of hydrogen content [27], using Equation (1), the values for the LHV of the materials are presented in Table 3.

Table 3. Lower Heating Value (LHV) of different particle sizes (considering $6 \%$ of hydrogen content in Equation (1)).

\begin{tabular}{ccc}
\hline Sample Identification & LHV [kcal/kg] & LHV [MJ/kg] \\
\hline wood chips & 4418 & 18.50 \\
wood shavings & 4460 & 18.67 \\
sawdust "light color" & 4478 & 18.75 \\
sawdust "dark color" & 4522 & 18.93 \\
\hline
\end{tabular}

Based on the values of the LHV of Table 3, in order to observe the influence of moisture content on the useful heating value, different values for $M C(30 \%, 40 \%, 50 \%, 60 \%$ and $70 \%)$ have been inserted in Equation (2). The results obtained are shown in Table 4 (in $\mathrm{kcal} / \mathrm{kg}$ ) and in Table 5 (in MJ $/ \mathrm{kg}$ ).

Table 4. Useful Heating Value (UHV, in $\mathrm{kcal} / \mathrm{kg}$ ) of different particle sizes at different moisture contents.

\begin{tabular}{cccccc}
\hline Sample Identification & UHV@30\% & UHV@40\% & UHV@50\% & UHV@60\% & UHV@70\% \\
\hline wood chips & 2912.6 & 2410.8 & 1909.0 & 1407.2 & 905.4 \\
wood shavings & 2942.0 & 2436.0 & 1930.0 & 1424.0 & 918.0 \\
sawdust "light color" & 2954.6 & 2446.8 & 1939.0 & 1431.2 & 905.4 \\
sawdust "dark color" & 2985.4 & 2473.2 & 1961.0 & 1448.8 & 936.6 \\
\hline
\end{tabular}

Table 5. Useful Heating Value (UHV, in MJ/kg) of different particle sizes at different moisture contents.

\begin{tabular}{cccccc}
\hline Sample Identification & UHV@30\% & UHV@40\% & UHV@50\% & UHV@60\% & UHV@70\% \\
\hline wood chips & 12.19 & 10.09 & 7.99 & 5.89 & 3.79 \\
wood shavings & 12.32 & 10.20 & 8.08 & 5.96 & 3.84 \\
sawdust "light color" & 12.37 & 10.24 & 8.12 & 5.99 & 3.87 \\
sawdust "dark color" & 12.50 & 10.35 & 8.21 & 6.07 & 3.92 \\
\hline
\end{tabular}

As observed from the Tables 4 and 5, the useful heating value decreased when the biomass moisture concentration increased. Although obvious, this observation is important in order to emphasize the large influence of the moisture content on the useful heating value and, as presented in Section 3.3, on the amount of material required to produce the same MWh of energy.

\subsection{Amount of Waste Required for the Generation of 1 MWh of Effective Thermoelectric Energy}

The required amount for waste needed to generate $1 \mathrm{MWh}$ of effective energy must be estimated based on the energy needs of the installed boiler, as well as the process efficiency and useful heating value. This makes it possible to determine the amount of material to satisfy the production of steam necessary for the operation of the turbogenerator [33].

Initially, the amount of energy (in $\mathrm{kWh}$ ) per kilogram of wood residue was determined through Equation (3), where a moisture content of $42 \%$ was considered as a reference value for obtaining the useful calorific power. Additionally, it has been considered an unit conversion that $1 \mathrm{kWh}$ represents $860 \mathrm{kcal} / \mathrm{h}$ [33].

$$
\left.E\right|_{1 \mathrm{~kg}}=\frac{U H V}{860}
$$

where $\left.E\right|_{1 \mathrm{~kg}}$ is the amount of energy (in kWh) per kilogram of residue. 
Considering an efficiency of approximately $20 \%$ for Thermoelectric power plants operating with the Rankine steam cycle, in order to generate $1000 \mathrm{kWh}$ of electricity, $5000 \mathrm{kWh}$ of energy have to be contained in the fuel, as presented in Equation (4).

$$
\left.m\right|_{1 \mathrm{MWh}}=\frac{E}{5000},
$$

where $\left.m\right|_{1 \mathrm{MWh}}$ is the mass of material required in order to generate $1 \mathrm{MWh}$ of energy.

The results for each sample type are presented in Table 6 .

Table 6. Amount of raw material $(\mathrm{kg})$ required to generate $1 \mathrm{MWh}$ of effective energy (considering $42 \%$ moisture content).

\begin{tabular}{ccc}
\hline Sample Identification & $\left.\boldsymbol{E}\right|_{\mathbf{1 ~ k g}}[\mathbf{k W h} / \mathbf{k g}]$ & $\left.\boldsymbol{m}\right|_{\mathbf{1 ~ M W h}}[\mathbf{k g} / \mathbf{M W h}] @ \mathbf{4 2} \mathbf{0}$ \\
\hline wood shavings & 2.714 & 1841.699 \\
sawdust "light color" & 2.727 & 1833.501 \\
sawdust "dark color" & 2.756 & 1813.764 \\
\hline average & 2.721 & 1837.520 \\
\hline
\end{tabular}

\subsection{Comparison of the Energy Performance of the Compacted Material against the "In} Natura" Material

In this subsection, the interest is to know the amount of energy provided by $1 \mathrm{~kg}$ of briquette. Considering the values obtained at the laboratory (LAPEM) from the samples collected in the region of Aripuanã, an energetic comparison was made between compacted waste such as briquettes and in natura waste to observe the influence of compaction on the waste mass needed to generate $1 \mathrm{MWh}$. According with the work of Matus et al. [34], the optimum moisture content of $8 \%$ is recommended in order to produce high-density briquettes. Hence, in order to calculate the useful heating value of the briquettes, $8 \%$ moisture content was considered. The same procedure adopted for the "in natura" material was repeated for the briquettes at $8 \%$ moisture, resulting in Table 7 . It is interesting to note that the briquettes could be made using all sorts of wood residues (as long as they had fine granulometry). Hence, the wood chips had to go through a chipper in order to reduce the particle size.

Table 7. Amount of raw material $(\mathrm{kg})$ required to generate $1 \mathrm{MWh}$ of effective energy using briquettes at $8 \%$ moisture content.

\begin{tabular}{cccc}
\hline Sample Identification & UHV & $\left.\boldsymbol{E}\right|_{\mathbf{1 ~ k g}}[\mathbf{k W h} / \mathbf{k g}]$ & $\left.\boldsymbol{m}\right|_{\mathbf{1} \mathbf{M W h}}[\mathbf{k g} / \mathbf{M W h}] @ \mathbf{8} \%$ \\
\hline wood chips & 4016.56 & 5.514 & 906.790 \\
wood shavings & 4055.2 & 5.563 & 898.829 \\
sawdust "light color" & 4071.76 & 5.584 & 895.460 \\
sawdust "dark color" & 4112.24 & 5.635 & 887.330 \\
\hline average & 4063.94 & 5.574 & 897.102 \\
\hline
\end{tabular}

Table 8 presents a comparison of the energy performance of the briquettes against "in natura" material, obtained from Tables 6 and 7, respectively. 
Table 8. Comparison of the energy performance of the briquettes against "in natura" material.

\begin{tabular}{ccc}
\hline Sample Identification & $\begin{array}{c}\text { Briquettes @8\% } \\
\text { kg/MWh }\end{array}$ & $\begin{array}{c}\text { “In Natura" @42\% } \\
\text { kg/MWh }\end{array}$ \\
\hline wood chips & 906.790 & 1861.117 \\
wood shavings & 898.829 & 1841.699 \\
sawdust "light color" & 895.460 & 1833.501 \\
sawdust "dark color" & 887.330 & 1813.764 \\
\hline average & 897.102 & 1837.520 \\
\hline
\end{tabular}

Figure 8 presents the same comparison of Table 8, however in a graphic. The goal of this figure is to provide a visual comparison on how the use of briquettes is more efficient than raw wood residues. From Table 8 and Figure 8, it can be seen that, with the use of briquettes, it was possible to reduce almost a ton of material in order to generate the same amount of energy. This is a consequence of briquetting process, where the materials were separated, dried and compressed. In this process, the moisture is removed from the material, in addition to the elimination of porosity. With these characteristics, the briquette has a heating value about twice the heating value of the "in natura" material. The "in natura" material has moisture and pores that concentrate air and have a calorific value as low as the moisture and porosity. This improves energy generation and enables the reduction of the costs associated with transportation ([35] pp. 227-232).

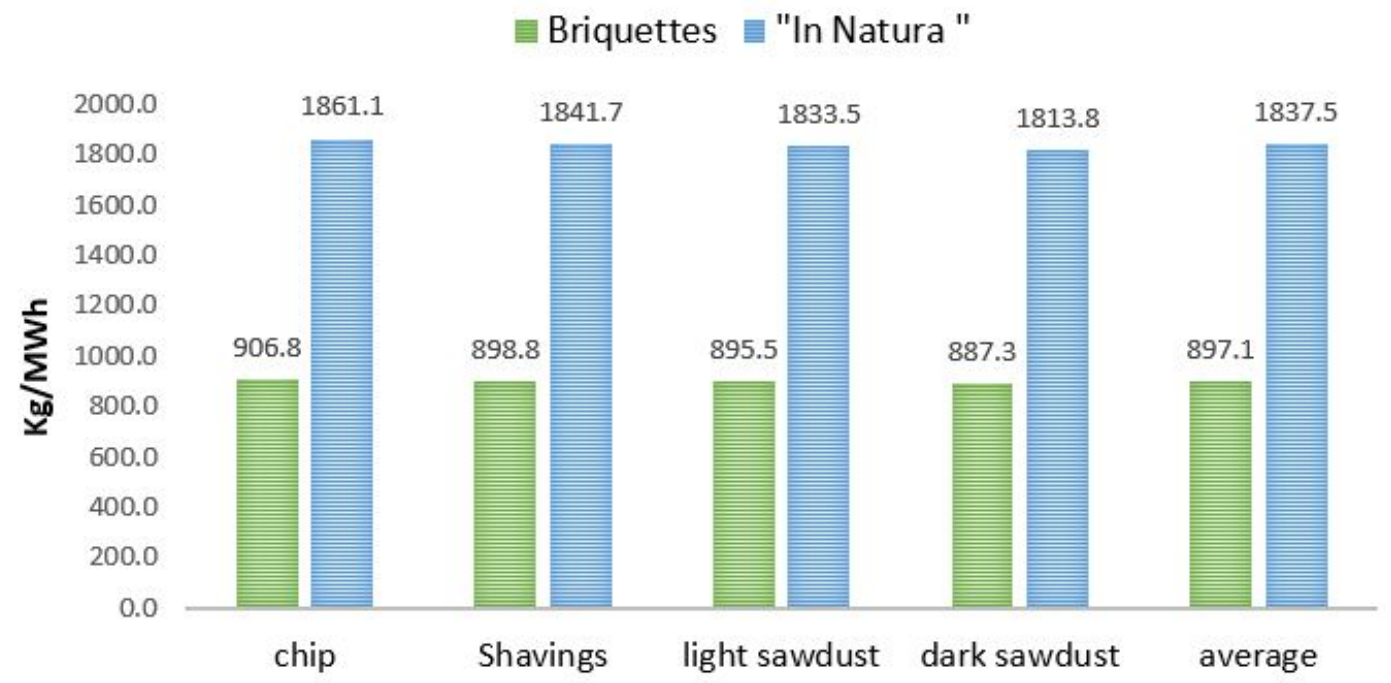

Figure 8. Comparison of the amount of waste required for the generation of $1 \mathrm{MWh}$ from briquettes and "in natura" material.

It can also be noted from Table 8 and Figure 8 that about half of the briquette mass promotes the same generation of electrical energy. This effect contributes to a reduction in the cost of acquiring raw material for generation, less $\mathrm{CO}_{2}[36,37]$ emissions, less generation of burning residues and better conservation of boiler equipment.

As the materials entering the plant are costed by weight, the reduction with transportation costs represents about $50 \%$ for the same hourly generation demand if received in the form of briquettes. This solves practical problems such as the provision of transport in the region and problems with roads and bridges. It makes transport effective and increases the plants' reliability for generating and fulfilling contractual supply targets. It is important to note that, without use of briquettes, the distances that the dump trucks must travel are within a radius of $120 \mathrm{~km}$. Using briquettes, just the raw material around the power plants is enough, as the briquettes have less moisture content and more useful heating value. 


\subsection{Cost Analysis}

From Table 8 , it can be noted that 0.8 ton of briquettes are required in order to produce $1 \mathrm{MWh}$ of energy and that 1.8 ton of raw waste at $45 \%$ moisture are required in order to produce the same $1 \mathrm{MWh}$. Considering only the operating costs of the Guacu plant and a gross generation of 18.1 MWh (actual data), a break even point of 11.25 BRL (roughly 2.14 USD) can be calculated between the generation with raw waste at (45\% moisture) and the generation with briquettes. This implies that, whenever the operational costs in order to generate electricity with raw waste is superior to $11.25 \mathrm{BRL} /$ ton, the use of briquettes is more viable.

As an example, it is known that the operational cost of Guacu plant is higher than 35.00 BRL. Hence, in order to produce $1 \mathrm{MWh}$ with raw material, the cost would be 63.00 BRL, while to produce the same MWh with briquettes it would be $51.04 \mathrm{BRL}$. The gain per MWh is $11.96 \mathrm{BRL}$. Considering an annual generation of $18.1 \mathrm{MW}$ at $24 \mathrm{~h}$ at 365 days, this implies in 158,556 MWh/year. Hence, the financial return can be calculated as $158,556 \mathrm{MWh}$ at $11.96 \mathrm{BRL} / \mathrm{MWh}: 1,896,329.76 \mathrm{BRL}$ (roughly 361,481.07 USD) per year.

\section{Conclusions}

This study demonstrated the high energy potential of wood processing residues produced in the Aripuanã region (which an important producer of wood in the Mato Grosso state, Brazil). This study also presented how the moisture concentration influences the energy properties of the waste used as fuel. The briquetting process presents itself as an alternative to obtain a better use of the energy contained in wood waste.

In the briquetting process, the materials are dried and compressed, which reduces substantially the moisture content and the material porosity. The low levels moisture concentration increases the energetic level in the fuel and, consequently, reduce the mass of wood waste needed in to generate the same amount of electricity.

Based on the results, it was found that the briquetting process also facilitates the storage and handling of fuel (as the briquettes have a higher density of stored energy). This enables a more efficient transportation of fuel (in briquette form) from the producing areas around the region of Aripuanã to the thermal power plants.

The paper presented all stages of the briquetting process and the calculations required in order to compare the amount of "in natura" material against the amount of briquetted material in order to generate $1 \mathrm{MWh}$ of energy. It has been found that almost $50 \%$ less wood residues would be required in briquette form in order to generate the same amount of electricity.

This system has been implemented in one of the three power plants in the Aripuana region (Brazil) recently in July 2021. So far, there are not enough data in order to compare the usage of residues after the implementation with the usage before. However, these data are expected to be reported in a future work. Additionally, as future work, it is expected an analysis of the briquette length and the physical characteristics to support storage and conveyors to the furnace. Additionally, it is expected to evaluated the procedures to adjust the compression pressure, compression chamber temperature and cut lengths. This methodology should guarantee the best burning performance in the boiler furnace.

Author Contributions: Conceptualization, R.M., C.B.B., L.E.L.O., E.L.B., H.F.V.-N., L.E.B.-d.-S., G.L.-T. and J.H.; investigation, H.d.N.C.-R., R.M., F.d.O.A., C.B.B., L.E.L.O., H.F.V.-N. and E.L.B.; methodology, H.d.N.C.-R., F.d.O.A., E.L.B., L.E.L.O. and G.L.-T.; writing, H.d.N.C.-R., H.F.V.-N. and W.C.S. All authors have read and agreed to the published version of the manuscript.

Funding: This research received no external funding.

Institutional Review Board Statement: Not applicable.

Informed Consent Statement: Not applicable.

Acknowledgments: The authors would like to thank Energética SUAPE II S.A., Guaçu Geração de Energia S.A. and ANEEL R\&D for the support of this project. 
Conflicts of Interest: The authors declare no conflict of interest.

\author{
Abbreviations \\ The following abbreviations are used in this manuscript: \\ ANEEL Agência Nacional de Energia Elétrica (Brazilian Electricity Regulatory Agency) \\ EIA U.S. Energy Information Administration \\ HHV Higher Heating Value \\ LAPEM Laboratório de Painéis e Energia da Madeira (Wood Panels and Energy Laboratory) \\ LHV Lower Heating Value \\ UHV Useful Heating Value
}

\title{
References
}

1. Tuoto, M. Levantamento Sobre a Geração de Resíduos Provenientes da Atividade Madeireira e Proposição de Diretrizes para Políticas, Normas e Condutas Técnicas para Promover o Seu Uso Adequado; Ministério do Meio Ambiente: Curitiba, Brazil, 2009.

2. Paula, L.E.; Trugilho, P.F.; Napoli, A.; Bianchi, M.L. Characterization of residues from plant biomass for use in energy generation. Cerne 2011, 17, 237-246. [CrossRef]

3. Li, I.; Hu, R. Sustainable biomass production for energy in China. Biomass Bioenergy 2003, 25, 483-499.

4. Tumuluru, J.S.; Wright, C.T.; Boardman, R.D.; Yancey, N.A.; Sokhansanj, S. A Review on Biomass Classification and Composition, Co-Firing Issues and Pretreatment Methods. In Proceedings of the ASABE Annual Meeting, Louisville, KY, USA, 7-10 August 2011; Volume 3. [CrossRef]

5. Quirino, W.F. Utilização Energética de Resíduos Vegetais; IBAMA, Laboratório de Produtos Florestais: Brasilia, Brazil, 2002.

6. Rosalino, T.; Dalfovo, W.C.T.A. Oroducao de residuos industriais madeireiros a partir da atividade das industrias madeireiras no municipio de Marcelandia-MT no período de 2007 a 2010. In Proceedings of the Congresso de Iniciacao Cientifica, Caceres, Brazil, 25 October 2011; Pro-Reitoria de Pesquisa e Pos-Graduacao, Universidade do Estado de Mato Grosso: Cáceres, Brazil, 2011.

7. Fontes, P.J.P.d. Auto-Suficiência Energética em Serraria de Pinus e Aproveitamento dos Resíduos; Universidade Federal do Parana: Curitiba, Brazil, 1994.

8. ANEEL. Sistema de Informações de Geração da ANEEL-SIGA—Online Database. 2021. Available online: https://www.aneel. gov.br/siga (accessed on 9 June 2021).

9. Fernandes, C.; Augusto, A.P.; Santos, I.; Souza, S. Produção de briquete industrial: Energia limpa e sustentável. In Proceedings of the Anais Congresso Brasileiro de Gestão Ambiental, Goiânia, GO, Brazil, 19-22 November 2012; Volume 3.

10. Aishwariya, S.; Amsamani, S. Exploring the Potentialities and Future of Biomass Briquettes Technology for Sustainable Energy. Innov. Energy Res. 2018, 7, 1463-2576. [CrossRef]

11. Kaur, A.; Roy, M.; Kundu, K. Densification of biomass by briquetting: A review. Int. J. Recent Sci. Res. 2017, 8, 20561-20568. [CrossRef]

12. Brunerova, A.; Roubik, H.; Brozek, M.; Herak, D.; Sleger, V.; Mazancova, J. Potential of Tropical Fruit Waste Biomass for Production of Bio-Briquette Fuel: Using Indonesia as an Example. Energies 2017, 10, 2119. [CrossRef]

13. Brunerová, A.; Brožek, M.; Šleger, V.; Nováková, A. Energy balance of briquette production from various waste biomass. Sci. Agric. Bohem. 2018, 49, 236-243. [CrossRef]

14. Jewiarz, M.; Wrobel, M.; Mudryk, K.; Szufa, S. Impact of the Drying Temperature and Grinding Technique on Biomass Grindability. Energies 2020, 13, 3392. [CrossRef]

15. Ullah, S.; Noor, R.S.; Gang, T. Analysis of biofuel (briquette) production from forest biomass: A socioeconomic incentive towards deforestation. Biomass Convers. Biorefinery 2021, 1-15. [CrossRef]

16. Zago, E.S.; Froehlich, A.G.; Pelegrini, P.H.; Sifuentes, M.A. O processo de briquetagem como alternativa de sustentabilidade para as indústrias madeireiras do município de Aripuanã-MT. Rev. TechnoEng. 2010, 2, 22-34.

17. Amaral, D.H. Potencial de Uso da Biomassa Florestal na Geracao de Energia Termica e Eletrica Pela Industria do Estado do Rio de Janeiro; Universidade Federal de Vicosa: Vicosa, Brazil, 2019.

18. Foelkel, C.E.B. Utilizacao da Biomassa do Eucalipto para Producao de Calor, Vapor e Eletricidade Parte 1: Biomassa Florestal \& Florestas Energeticas. In Eucalyptus Online Book E Newsletter; 2016. Available online: https://www.eucalyptus.com.br/ eucaliptos/PT43_Florestas_Energeticas_Eucaliptos.pdf (accessed on 4 October 2021).

19. Quirino, W.F.; Vale, A.d.; Andrade, A.d.; Abreu, V.L.S.; Azevedo, A.d.S. Poder calorífico da madeira e de materiais lignocelulósicos. Rev. Madeira 2005, 89, 100-106.

20. Phyllis Online Database. 2021. Available online: https:// phyllis.nl/Home/Help (accessed on 27 September 2021).

21. U.S. Energy Information Administration. Search for 'Heating Value' at the Online Glossary. 2021. Available online: https: / / www.eia.gov/tools/glossary/ (accessed on 13 September 2021).

22. Cortez, L.A.B.; Lora, E.S.; Gomez, E.O. Biomassa para Energia; UNICAMP: Campinas, Brazil, 2008

23. Rodrigues, T.O.; Rousset, P.L. Effects of Torrefaction on Energy Properties of Eucalyptus grandis Wood. Cerne 2009, 15, 446-452.

24. Brito, J.O. Expressão da produção florestal em unidades energéticas. In Proceedings of the Congresso Florestal Panamericano, Curitiba, Brazil, 19-24 September 1993; Volume 1, pp. 280-282. 
25. Goncalves, J.E.; Sartori, M.M.; Leao, A.L. Energia de briquetes produzidos com rejeitos de residuos solidos urbanos e madeira de Eucalyptus grandis. Rev. Bras. Eng. Agric. Ambient. 2009, 13, 657-661. [CrossRef]

26. Pacheco, J.M.; Lima, R.; Sehgal, D.; Mangueira, R.A.F.; Teixeira, S.; Filho, C.A.F. Quantification analysis unravels significance of residual biomass of Pinus taeda L. Aust. J. Basic Appl. Sci. 2020, 14, 1-9. [CrossRef]

27. Ferreira, I.T.; Schirmer, W.N.; de Oliveira Machado, G.; Gueri, M.V.D. Estimativa do potencial energético de resíduos celulósicos de fabricação de papel através de análise imediata. Rev. Bras. Energias Renov. 2014, 3, 284-297. [CrossRef]

28. Quirino, W.F.; Brito, J.O. Características e índice de Combustão de Briquetes de Carvão Vegetal; IBAMA, Laboratório de Produtos Florestais: Brasilia, Brazil, 1991.

29. Quirino, W.F.; de Oliveira Pinha, I.V.; de Oliveira Moreira, A.C.; de Souza, F.; Filho, M.T. Densitometria de raios x na análise da qualidade de briquetes de resíduos de madeira X Ray densitometry for waste wood briquetts analysis. Sci. For. 2012, 40, 525-536 .

30. Konishi, P.A.; Yamaji, F.; Silva, D.; Wanderley, C. Influencia do teor de umidade na confeccao de briquetes de serragem de Pinus sp. In Proceedings of the Congresso de Iniciacao Cientifica, Campinas, Brazil, 26-30 September 2011; Universidade Federal de Sao Carlos, USFSCAR: Sao Carlos, Brazil, 2011.

31. Longjian, C.; Xing, L.; Lujia, H. Renewable Energy from Agro-Residues in China: Solid Biofuels and Biomass Briquetting Technology Renewable and Sustainable Energy Reviews. Renew. Sustain. Energy 2009, 13, 2689-2695.

32. Filippetto, D. Briquetagem de Residuos Vegetais: Viabilidade Tecnico-Economica e Potencial de Mercado; Unicamp: Campinas, Brazil, 2008.

33. Castells, X.E. Reciclaje de Residuos Industriales: Residuos Sólidos Urbanos y Fangos de Depuradora; Ed. Díaz de Santos: Madrid, Spain, 2012.

34. Matúš, M.; Križan, P.; Beniak, J.; Šooš, L'. Effects of initial moisture content on the production and quality properties of solid biofuel. Acta Polytech. 2015, 55, 335-341. [CrossRef]

35. El Haggar, S. Sustainable Industrial Design and Waste Management: Cradle-to-Cradle for Sustainable Development; Academic Press: San Diego, CA, USA, 2010. [CrossRef]

36. Shuma, R.; Madyira, D.M. Emissions Comparison of loose biomass briquettes with cow dung and cactus binders. Procedia Manuf. 2019, 35, 130-136. [CrossRef]

37. Pilusa, T.J.; Huberts, R.; Muzenda, E. Emissions analysis from combustion of eco-fuel briquettes for domestic applications. J. Energy S. Afr. 2013, 24, 30-36. [CrossRef] 